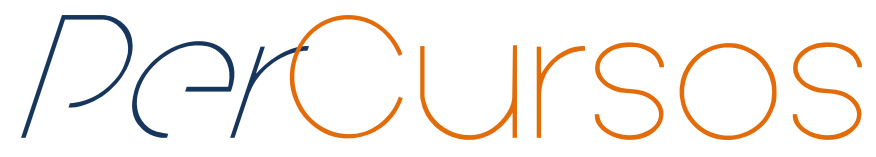

\title{
Entre a cruz e o terreiro: uma análise em torno da integração entre a religiosidade afro-brasileira e o Ensino de História no Museu do Negro do Rio de Janeiro ${ }^{1}$
}

\begin{abstract}
Resumo
Nos últimos anos, a formação de professores e a produção de materiais didáticos tem se aperfeiçoado no sentido de atender as demandas inauguradas pela Lei 10.639/03. Entretanto, percebe-se que, apesar do esforço para evitar o eurocentrismo, compreender africanos e afrobrasileiros enquanto agentes históricos ativos e valorizar a cultura de matriz africana, os temas ligados à religiosidade africana e afro-brasileira seguem silenciados nas salas de aula. Neste trabalho, problematizamos a persistente marginalização das manifestações culturais ligadas à temática religiosa no Ensino de História. Tomamos por objeto, como estudo de caso, a exposição do Museu do Negro do Rio de Janeiro para explicitar a possibilidade de uma abordagem histórica que integre aspectos culturais, atribuindo historicidade aos mesmos, visto que, o Museu do Negro aciona a cultura afro-brasileira, como espaço de resistência, para construir narrativas históricas sobre a população negra em diferentes períodos.
\end{abstract}

Palavras-chave: Museu do Negro (Rio de Janeiro, RJ). História - Estudo e Ensino. Antirracismo. Educação Multicultural.
Jessika Rezende Souza da Silva

Doutoranda em Educação pela Universidade Federal do Rio de Janeiro - UFRJ. Mestre em

Ensino de História pela Universidade Federal do Rio de Janeiro - UFRJ. Professora de História da rede pública estadual do Rio de Janeiro- SEEDUC-RJ. Brasil jessikasouza7@gmail.com

\footnotetext{
Para citar este artigo:

SOUZA, Jessika Rezende. Entre a cruz e o terreiro: uma análise em torno da integração entre a religiosidade afro-brasileira e o Ensino de História no Museu do Negro do Rio de Janeiro. Revista PerCursos, Florianópolis, v. 20, n.44, p. 155 -189, set./dez. 2019.
}

\section{DOI: $10.5965 / 1984724620442019155$}

http://dx.doi.org/10.5965/1984724620442019155

\footnotetext{
${ }^{1}$ As entrevistas e fotografias apresentadas neste artigo foram realizadas durante o projeto de pesquisa Entre a cruz e o terreiro: uma análise em torno da integração entre a religiosidade afro-brasileira e o Ensino de História no Museu do Negro, cujo resultado foi a dissertação de mestrado homônima
} 


\title{
Between the cross and the terreiro: an analysis around the integration among the Afro-Brazilian religiosity and the Teaching of History at the Museu do Negro in Rio de Janeiro (Brazil)
}

\begin{abstract}
In recent years, teacher training and the production of teaching materials have been improved to meet the demands of the Law 10.639 / 03. However, despite efforts to avoid Eurocentrism and to understand Africans and Afro-Brazilians as active historical agents, issues related to African and Afro-Brazilian religiosity are still silenced in classrooms. In this article, we problematize the marginalization of religious themes in the history teaching, even after the implementation of Law 10639/03. In this research, we analyze, as a case study, the permanent exhibition of the Museu do Negro. Our goal is to make possible the possibility of a historical approach that integrates religious aspects, since the Museu do Negro activates Afro-Brazilian culture, as a space of resistance, to construct historical narratives about the black population in different moments.
\end{abstract}

Keywords: Negro Museum (Rio de Janeiro, RJ). History - Study and Teaching. Anti-racism. Multicultural Education. 
Resultado de anos de mobilizações e lutas dos movimentos negros, a Lei 10.639, de 2003, tornou obrigatório o ensino de história e cultura africana e afro-brasileira na educação básica e, nos últimos anos, a formação de professores e a produção de materiais didáticos tem se aperfeiçoado no sentido de atender as demandas inauguradas por ela. Novos lugares de memória têm sido definidos na perspectiva de promover a reavaliação do papel dos negros na história ensinada nas escolas. Os esforços por compreender africanos e afro-brasileiros como sujeitos históricos ativos e valorizar a cultura de matriz africana tem avançado, porém os temas ligados à religiosidade africana e afro-brasileira seguem silenciados nas salas de aula. Cultos e manifestações culturais religiosas de origem africana têm sido relegados ao âmbito do Ensino Religioso, quando não ocorre uma rejeição completa de professores e alunos a tratar esse tema, o que não costuma ocorrer com outras vertentes religiosas

O trabalho no cotidiano escolar requer muito cuidado para não se precipitar em reducionismos, maniqueísmos e na exotização de tudo aquilo que tem origem no continente africano. Como pensar a diferença e a diversidade cultural nos currículos de história, num país marcado por um projeto de colonização que procurou homogeneizar, obliterando as diferenças? Consideramos, de acordo com Bhabha (1998, p. 227) que a diferença cultural "não pode ser compreendida como um jogo livre de polaridades e pluralidades no tempo homogêneo e vazio da comunidade nacional", visto que possibilidades de conflitos e resistências se materializaram no campo da cultura, produzindo construções identitárias híbridas, produzidas a partir de negociações, que não apagam hierarquizações, conflitos e posições de poder ou as perspectivas das minorias.

O objetivo da diferença cultural seria, segundo Bhabha (1998. p.228), rearticular a soma do conhecimento a partir da perspectiva da posição de significação da minoria, que resistiu à totalização e tem criado estratégias políticas e discursivas que serviriam para perturbar o cálculo de poder e saber, produzindo outros espaços de significação subalterna. Nesse sentido, problematizamos o currículo de história brasileiro, inaugurado sob a égide da modernidade ocidental que condenava à invisibilidade as formas de conhecimento que não se encaixavam nas epistemologias dominantes (SANTOS; 
MENESES, 2010, p. 32) e, ainda hoje, segue marginalizando as culturas dos povos não brancos. Neste artigo, buscamos, através de uma abordagem integrada das manifestações culturais afro-brasileiras no ensino de história, visibilizar narrativas performáticas em que os discursos das minorias emergem (BHABHA, 1998, p. 218).

A Lei 10639/03, ao instituir a obrigatoriedade do ensino de história e cultura afrobrasileira, ampliou as possibilidades de mudança de um currículo historicamente racista e colonialista, todavia, no processo de ruptura com a epistemologia eurocêntrica são necessárias negociações com as diferentes culturas e pertencimentos dos sujeitos envolvidos no processo educativo e com a temporalidade continuísta, que faz presentes nas salas de aula estereótipos de inferioridade da raça negra e o mito da democracia racial. Conforme afirma Hall (2003, p.343), as culturas negras têm se construído nos espaços performáticos que foram possíveis na diáspora, através de suas heranças, de um patrimônio africano e da "apropriação, cooptação e rearticulação seletivas de ideologias, culturas e instituições europeias".

\section{Currículo e cultura afro-brasileira no Ensino de história}

A trajetória das manifestações culturais de matriz africana no Brasil tem sido marcada pela perseguição e pelo preconceito. Durante anos, a prática do candomblé e da capoeira, por exemplo, eram proibidas por lei. Capoeiristas eram presos e terreiros eram invadidos e saqueados. Esse tipo de ação não foi erradicada com a legislação que institucionalizou os direitos de cidadania aos seguidores de diferentes religiões e criminalizou a intolerância, de forma que a religiosidade afro-brasileira ainda é alvo de ataques, tanto de violência física, quanto de violência simbólica (LIMA, 2016). Nas escolas, a cultura afro-brasileira aparece com dia e hora marcada, e não costuma fazer parte do currículo escolar, pois ficaria relegada ao "currículo turístico”, ou seja, suas manifestações são introduzidas no espaço escolar como contribuições esporádicas, banais, sem o aprofundamento necessário para compreender o modo como foram/são vivenciadas (SANTOMÉ, 2011, p. 254). No âmbito do ensino de história, a abordagem das 
manifestações culturais tem provocado rejeição por parte de professores, estudantes e familiares, conforme relatam Pereira e Roza (2012, p. 92):

Uma das mais fortes tensões deste período pode ser visualizada por meio da negativa de comunidades de pais e responsáveis, que se posicionam contrárias à introdução de conteúdos da história e da cultura africanas e afro-brasileiras nos currículos escolares. Motivadas por pressupostos morais e religiosos, essas comunidades expressam receio de que crianças e jovens estejam expostos a proselitismo religioso ao estudarem ou entrarem em contato com manifestações tradicionais africanas e afro-brasileiras.

Os rituais religiosos ganham visibilidade na diversa herança cultural africana como os mais hostilizados. Livros e outros materiais didáticos que tratam dessa temática são acusados de doutrinação religiosa. Lendas e mitos da tradição oral afro-brasileira são excluídos do espaço escolar como se nada oferecessem ao aprendizados dos estudantes. Souza (2012, p. 21) indica que a abordagem desses aspectos da cultura afro-brasileira aumentaria a dificuldade da implantação real da Lei 10.639/03, pois seriam estes os que provocariam maior resistência junto a professores e alunos devido à oposição aberta dos adeptos de religiões evangélicas quanto ao ensino de cultura afro-brasileira (SOUZA, 2012, p. 20). No que diz respeito ao ensino de história, não é raro encontrar professores que se esquivam de uma abordagem mais profunda e contextualizada desses aspectos culturais, alegando que não caberia ao professor de história e sim ao de ensino religioso tratar dessa questão.

O currículo de história, no entanto, inclui inúmeras manifestações e movimentos religiosos em seus conteúdos disciplinares, como, por exemplo, a mitologia grega e romana, os rituais religiosos de incas e astecas, o judaísmo e o islamismo, sem falar, no cristianismo católico e protestante. Todos esses assuntos são recorrentemente trabalhados em sala de aula, e não costumam causar rebuliço. Tanto professores, como estudantes e seus familiares, parecem reconhecer tais assuntos como legítimos e componentes importantes para a compreensão de processos históricos, na medida em que, os aspectos religiosos acima citados são estudados em conjunto com outros 
aspectos da sociedade no contexto histórico que está sendo trabalhado pelo professor.

Diante disso, acreditamos, que da mesma forma, no que diz respeito ao estudo da história afro-brasileira, os aspectos culturais, inclusive os religiosos, podem e devem ser acionados para uma compreensão mais complexa dos processos históricos protagonizados pelas populações negras, bem como, para a construção de narrativas históricas que propiciem a reavaliação do papel dos negros.

\section{Museus no Ensino de História: lugares de memórias e construção de saberes}

Movimentos sociais, amparados pela perspectiva do dever de memória e da memória reivindicativa, assim como a agenda legal de valorização da diversidade tem motivado a criação de novos "lugares de memória", adequados aos novos discursos. Consideramos memória uma construção social, que como tal, responde aos interesses do presente e é permeada por disputas de poder, de enquadramentos, apropriações e negociações que se dão no presente. Nessa direção, Nora (1993, p. 21) define os lugares de memória como frutos do sentimento de que não há memória espontânea e logo, "é preciso ter vontade de memória", isto é, criar arquivos, montar exposições, manter aniversários, organizar celebrações a fim de bloquear o trabalho do esquecimento, fixar um estado de coisas. Além disso, para ser tratado como "lugar da memória", esse lugar precisa ser reconhecido como tal, seja por um indivíduo, por um grupo social ou por toda uma sociedade.

Os museus são espaços privilegiados de construção de memórias e narrativas históricas, e têm se reformulado para os tempos contemporâneos priorizando seus objetivos educacionais. O Departamento de Museus e Centros Culturais (DEMU) IPHAN/MinC (BRASIL, 2006) destacou como funções intrínsecas dos museus o uso do patrimônio como recurso educacional, de forma que tais instituições desempenhariam um papel pedagógico junto aos cidadãos. O museu, por sua vez, não substitui a escola, nem seria uma extensão dela. É um espaço de educação, de construção de saberes a partir do exercício de reflexão sobre as múltiplas relações entre o presente e o passado através dos objetos no espaço de exposição. 
Diferentes dos currículos escolares, que são mais rigidamente regulados e monitorados, as exposições de museus são muito mais responsivas a revisões históricas como a proposta pela Lei 10.639/03 (AUTRY, 2017, p.20). No contexto das instituições museais, as mudanças têm se intensificado a partir do Decreto 3.551 de 2000, que instituiu o registro de bens culturais de natureza imaterial e tornou possível reconhecer, valorizar e salvaguardar os patrimônios imateriais relativos a heranças de populações escravizadas. As políticas públicas nacionais têm fomentado medidas de democratização e de valorização das culturas em sua multiplicidade, como por exemplo, a Política Nacional de Cultura do Instituto Brasileiro de Museus, que promove um olhar positivo e inclusivo sobre grupos anteriormente marginalizados (MELLO, 2013, p.54).

Desde a segunda metade do século $\mathrm{XX}$, no ensejo dos debates sobre a denúncia do mito da democracia racial, já começavam a surgir os museus afro-brasileiros, cujo objetivo era divulgar novas imagens das populações negras para o grande público, a partir da valorização de obras de artistas negros e objetos de origem e/ou inspiração africana (SANTOS, M., 2005, p. 41). Dentre os museus afro-brasileiros mais conhecidos podemos citar o Museu do Negro, fundado em 1967 no Rio de Janeiro; o Museu Afro-Brasileiro, criado em 1976 no Sergipe, o Museu Afro-Brasileiro (MAFRO), inaugurado em 1982, em Salvador, e o Museu Afro-Brasil, cuja criação se deu no ano de 2004, em São Paulo.

O Museu Afro-Brasileiro de Salvador, o MAFRO, e o Museu Afro-Brasil, segundo Myriam Sepúlveda dos Santos (2005, p.41), já sinalizam as mudanças radicais na forma de representar o negro, já marcadas pela "racialização da cultura brasileira" ligada ao recente fortalecimento de políticas públicas de combate às desigualdades raciais e das ações afirmativas. O Museu do Negro que, por sua vez, foi o precursor do movimento de valorização da presença e da experiência histórica dos africanos e seus descendentes na cidade do Rio de Janeiro, seria "o elo perdido entre os velhos e novos museus afrobrasileiros" (SANTOS, M., 2000, p. 9), em que o tema das relações raciais apareceria entrelaçado ao tema da história e da constituição da memória nacional, e a cultura negra seria acionada na construção de uma narrativa que enfatiza suas lutas e sofrimento. 
Irmandade de Nossa Senhora do Rosário e São Benedito dos Pretos: espaço

O Museu do Negro está situado no segundo andar da Igreja de Nossa Senhora do Rosário e São Benedito dos Homens Pretos e é gerido pela Irmandade de mesmo nome, fundada por negros alforriados e escravizados em 1640. No Brasil, as irmandades dedicadas a Nossa Senhora do Rosário foram as mais numerosas e disseminadas. De acordo com Paiva (2007a, p.206), tal popularidade se devia ao fato de que culto a Nossa Senhora do Rosário já era praticado pelos negros desde os séculos XV e XVI em Portugal, onde havia sido adotada como padroeira de vários grupos. Em 1639, no Rio de Janeiro, os devotos da Santa, que tinha a sua imagem na Igreja de São Sebastião, no Morro do Castelo, fundaram uma confraria, que existiu simultaneamente a outra, dedicada a São Benedito. Ambas foram fundadas por negros, livres e escravizados. Em 1667, elas se fundiram, pois o mesmo Provedor havia assumido a direção das duas irmandades.

Era costume que os negros libertos fizessem valiosas doações para essas associações religiosas, rendendo graças por sua libertação, e assim as irmandades acumulavam meios para alforriar outros escravizados, bem como, construir belas igrejas em homenagem a seus santos padroeiros (PAIVA, 2007a, p. 208). Problemas de ordem da administração religiosa nos anos seguintes à fundação da Irmandade despertaram nos devotos o desejo de retirar seus pertences da Igreja de São Sebastião e os teria levado a decisão de construir sua própria igreja em um terreno que havia sido doado à irmandade, situado na Rua dos Latoeiros, à beira da Vala. O edifício que seria erguido na antiga Rua da Vala, hoje Rua Uruguaiana, teve então sua construção iniciada no ano de 1700 e levou 25 anos para ser terminado.

Uma igreja construída por meio da associação de negros libertos e escravizados, com o intuito de cultuar seus padroeiros e enterrar seus mortos, cuja grande quantidade de instrumentos de tortura e outros artefatos históricos acabou por dar origem a um museu. A Igreja de Nossa Senhora do Rosário e São Benedito dos Homens Pretos nos parece um importante lugar da memória da herança africana e afro-brasileira no Rio de 
Janeiro, apesar de não fazer parte do "Circuito Histórico e Arqueológico de Celebração da Herança Africana" da cidade. A diretoria do museu do Negro explica que:

A nossa irmandade não entrou por motivos de política interna...Cais do Valongo, Pedra do Sal, IPN, Morro da Conceição, tudo num grupo só, e nossa Irmandade, ela está um pouco afastada. É como se tivesse uma Ponte Rio-Niterói, uma Baía de Guanabara entre nós. Só que eles esquecem de uma coisa, a nossa briga, do Museu do Negro e da Irmandade, a nossa briga é que todo esse povo começou aqui na Irmandade. Eles alegam que com o incêndio de 1967 a Irmandade acabou. Tanto é que quando você vai falar com Fajardo: "Ué mas a irmandade não acabou em 1967?", aí eu digo: "ela está mais viva do que nunca" (PASSOS, 2016. Informação oral). ${ }^{3}$

Apesar de a irmandade reivindicar, não sem razão, fazer parte fundamental do cotidiano dos negros que habitavam o Centro do Rio de Janeiro desde o século XVII, o contexto em que a Igreja de Nossa Senhora do Rosário e São Benedito dos Homens Pretos foi tombada pelo IPHAN foi bastante diferente da política patrimonial que contemplou o Cais do Valongo e adjacências. A igreja teve seu tombamento registrado em 7 de abril de 1938, sob o número de processo 0018-T-38, nos Livros de Belas Artes e Histórico. O processo estava incluído nos primeiros tombamentos do SPHAN, inaugurado no ano anterior, com objetivo de identificar e preservar as obras de civilização.

A prática de tombamento, iniciada no início de 1938, teve até dezembro do mesmo ano, 215 livros inscritos em seus livros do tombo. Segundo Rubino (1996, p. 98), o conjunto eleito naquele momento como patrimônio histórico e artístico nacional remetia a fatos memoráveis e personagens ilustres de um país com "quatro séculos de história, extremamente católico, guardado por canhões, patriarcal, latifundiário, ordenado por intendências e casas de câmara e cadeias, e habitado por personagens ilustres". Dessa

\footnotetext{
${ }^{2}$ Washington Fajardo foi subsecretário de Patrimônio Cultural, Intervenção Urbana, Arquitetura e Design e, a partir de 2012, foi presidente do IRPH (Instituto Rio Patrimônio da Humanidae). O órgão municipal é responsável por cuidar dos aspectos culturais, históricos e urbanos do patrimônio da cidade.

${ }^{3}$ Ricardo Passos é historiador e ocupa o cargo de diretor e coordenador geral do Museu do Negro desde sua reabertura, há dez anos. Além de responsável pela curadoria da exposição atual da instituição, ele também é membro da Irmandade de Nossa Senhora do Rosário e São Benedito dos Homens Pretos, na posição de Irmão Leigo. Entrevista cedida ao autor, no Museu do Negro em 07/07/2016.
} 
forma, o SPHAN documentava fatos históricos, lugares hegemônicos, mapeando não apenas um passado, mas o passado que aquela geração desejava deixar como legado.

A Igreja de Nossa Senhora do Rosário e São Beneditos dos Homens Pretos figurava entre esses legados. Naquele momento, o valor histórico atribuído ao prédio se devia ao fato de entre 1737 e 1808, a Igreja ter sediado a Catedral do Rio de Janeiro e ter sido o primeiro local visitado por D. João, em 1808, após sua chegada à cidade, para render graças pelo término bem sucedido da viagem ao Brasil. Além disso, nesta Igreja, foi entregue, por uma comissão da Câmara, o abaixo assinado, em 9 de janeiro de 1822, pedindo a D. Pedro I que ficasse no Brasil, dia que ficou conhecido como Dia do Fico, e nela foi sepultado Mestre Valentim, grande artista da cidade no século XVIII.

A irmandade, ainda hoje, se preocupa em manter vivo o reconhecimento da Igreja como sede de importantes cenários da política no período imperial. No banner [figura 1] que decora o corredor de entrada do Museu do Negro está escrito: "Aqui nasceu a Pequena África", em que a instituição reivindicaria seu lugar como patrimônio da história e cultura afro-brasileira. Entretanto, na imagem central, o que se vê é uma representação da chegada da família real e sua corte à igreja. D. João é representado no plano principal, seguido de outras pessoas brancas. Os negros acabam aparecendo num plano secundário. A mesma imagem também tem destaque no site da irmandade. Outras figuras monárquicas, como a Princesa Isabel e o Conde D’eu são homenageados pelo Museu do Negro, além de dar grande importância ao título de "Imperial” Irmandade de Nossa Senhora do Rosário e São Benedito dos Pretos, conforme se pode observar no logotipo da irmandade, decorado como a coroa [figura 2]. 
Figura 1- Banner localizado no corredor de entrada do Museu do Negro

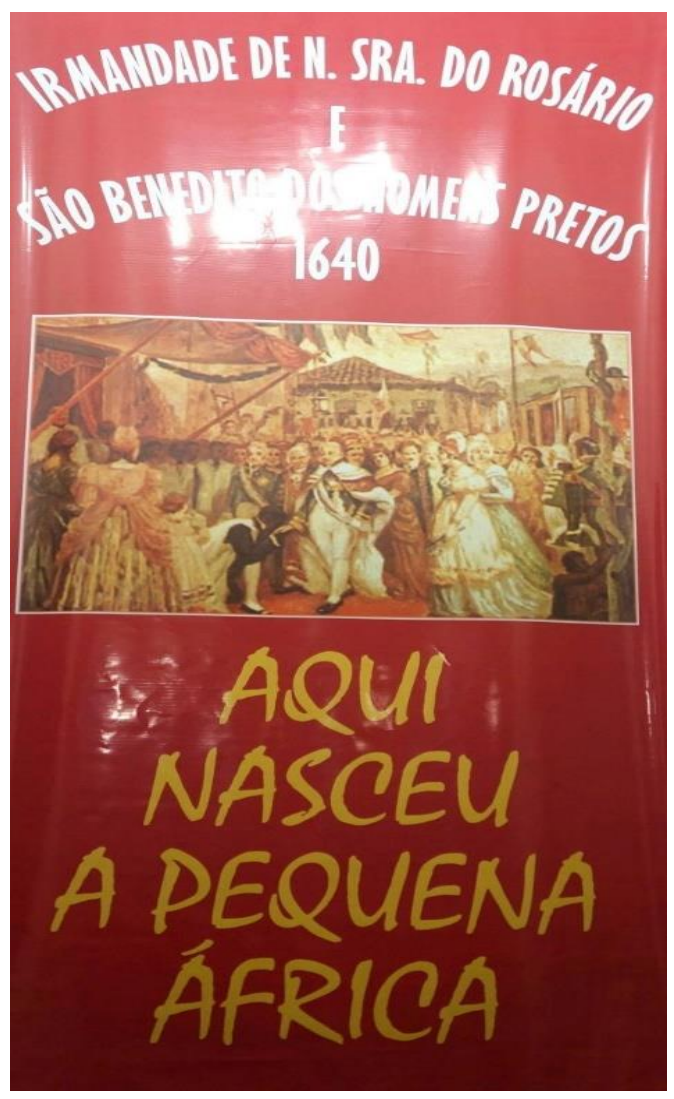

Fonte: Elaborada pelo autor, 2016.

Figura 2- Logotipo da Irmandade

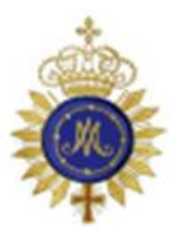

\section{IMPERIAL IRMANDADE DE NOSSA SENHORA DO ROSÁRIO E SÄO BENEDITO DOS HOMENS PRETOS}

Fonte: Website do Museu do Negro: http://irmandadedoshomenspretos.org.br/site/ Acessado em 28 jul.2016.

A Irmandade de Nossa Senhora do Rosário e São Benedito dos Homens Pretos constitui um importante lugar de memória na narrativa da história afro-brasileira; entretanto, o processo que promoveu a patrimonialização da Igreja estava calcado em 
uma perspectiva complemente diversa às atuais orientações políticas de revitalização da Pequena África, o que em parte pode explicar sua não inclusão, bem como a do Museu do Negro, no "Circuito Histórico e Arqueológico de Celebração da Herança Africana”, apesar de estar geograficamente próximo e compartilhar de idêntico valor histórico.

A criação do Museu do Negro remonta à época de reconstrução da igreja, em razão do incêndio ocorrido na noite de 25 de março de 1967. A possibilidade de perder o acervo secular de documentos, objetos de devoção e todo tipo de relíquia que era guardada na igreja, teria motivado o, então provedor da irmandade, Marechal João Baptista de Matos, a criar o Museu do Negro para que com a preservação dessas peças não se perdesse uma parte importante da história do negro no Brasil.

A igreja foi reaberta em 1969, e no mesmo ano foi inaugurado o Museu do Negro, uma instituição privada, porém, aberta à visitação pública e gratuita, de segunda a sextafeira, entre às 10 e 17 horas. Gerido por uma irmandade católica, e localizado no segundo andar da Igreja de Nossa Senhora do Rosário e São Benedito dos Homens Pretos, o museu está dividido em três partes: a sala de entrada; uma pequena sala lateral à esquerda desta primeira e a sala Yolando Guerra. A proximidade física entre ambos nos leva a refletir sobre as relações entre o lugar de construção de memória e o espaço de devoção dos irmãos. Seria o museu também um lugar de culto? Uma extensão da igreja? Durante as entrevistas com a diretoria do museu e com irmãos devotos do Rosário, percebemos como esses limites são fluidos.

O museu em evidência está colocando a irmandade. O museu entrou agora no Guia Histórico, se eu estou falando do museu, estou falando da irmandade. Se estou falando da irmandade, lógico que tenho que falar do museu, ou seja o foco era para ser a irmandade mas o foco tem sido o museu. Na realidade, o foco tem que ser os dois, porque o que é o museu? Esse local aqui mais o prédio histórico. [...] São coisas distintas e ao mesmo tempo não são coisas distintas. O museu ficou fechado por 10 anos. Um grupo de malucos resolveram reabrir o museu com a finalidade de reavivar a memória não só da igreja e da irmandade, mas a história do movimento negro no Brasil ${ }^{4}$ (PASSOS, 2016. Informação oral).

\footnotetext{
${ }^{4}$ Ricardo Passos, historiador e coordenador do Museu do Negro. Entrevista cedida ao autor em 07/07/2016.
} 
Museu e igreja compartilham uma trajetória e dividem mais do que simplesmente o espaço físico. A diretoria do museu está composta, atualmente, por dois historiadores, um diretor patrimonial e um museólogo, todos membros da irmandade, com exceção do último. Na entrevista com o grupo, percebemos que museu e igreja se confundem no que tange a promoção do reconhecimento do valor histórico da Irmandade de Nossa Senhora do Rosário e São Benedito dos Homens Pretos, entretanto, o museu teria uma incumbência a mais: a de inserir a irmandade na trajetória de lutas da população negra, conforme afirmou o diretor de patrimônio da instituição, que tem cuidado do acervo há cerca de doze anos: “Hoje a gente pensa no mundo, não é uma coisa privada, tem que ser divulgada para o mundo todo, para que o mundo conheça a importância da história da igreja ${ }^{5} "$ (MOREIRA, 2016. Informação oral).

\section{Museu de quem? Do escravizado, do resistente, do negro?}

Antes de ser chamado de "Museu do Negro", a instituição já foi chamada de “Museu dos Escravos" e “Museu da Abolição". Paiva (2007a, p.209) relata que a primeira denominação do museu apareceu em um jornal não datado e sem referência trazendo um texto intitulado "Obras de arte e documentos valiosos fazem parte do Museu dos Escravos", em que se falava sobre suas coleções de objetos valiosos que remetiam ao período escravista no Brasil. Em outro jornal, possivelmente publicado na década de 1960, a autora encontrou a manchete "Aberto o Museu da Abolição em homenagem ao 13 de Maio", que comemorava a iniciativa da Irmandade de franquear a visita ao museu, à missa solene, às coleções de documentos e às peças relacionadas à Campanha Abolicionista. Em ambos os jornais, os textos explicitam o endereço em que se localizam o museu, na Igreja de Nossa Senhora do Rosário, na Rua Uruguaiana. Assim, evidencia-se que, apesar da incerteza das datas, trata-se da mesma instituição.

Os diferentes nomes estão intimamente ligados ao enfoque que se dava aos artefatos pertencentes à Irmandade. Tanto se podem enfatizar as dores da escravidão, como se pode enfatizar a luta pela liberdade. Portanto, o mesmo acervo pode construir

\footnotetext{
${ }^{5}$ Irmão Jocimar Moreira, diretor de patrimônio do Museu do Negro. Entrevista cedida em 07/07/2016.
} 
diferentes identidades e diferentes narrativas sobre a história dos negros. As mutantes designações revelam parte da difícil tarefa de representar uma população heterogênea e de experiências históricas tão diversas como a população negra, o que acaba por suscitar tensões e confrontos ao interligar narrativas, práticas e representações culturais distintas em torno de uma questão: o que se quer lembrar? A resposta a esses questionamentos pode ser encontrada a partir dos objetos selecionados para compor a exposição permanente no referido museu. No site da instituição, o Museu do Negro apresenta seu acervo como:

Composto por esculturas, fotografias, indumentária e documentos, dentre outros, com destaque para as santidades católicas, paramentos litúrgicos e dos membros da irmandade; os objetos ligados à escravidão (instrumentos de suplício e do cotidiano); objetos de culto ligados ao Candomblé, imagens e indumentária representativas da africanidade, da "Mãe África" e da "Mulher Negra"; objetos ligados ao Movimento Abolicionista e à Monarquia como dois estandartes abolicionistas salvos do incêndio, utilizados na procissão de despojo dos ossos da Princesa Isabel e do Conde D’Eu, na década de 1970 (MUSEU DO NEGRO, 2016).

A mencionada escultura da Mãe-África [figura 3], de autoria não conhecida, pode ser considerada como mediadora entre uma memória passada e o presente. A estátua de bronze de uma negra sorridente, segurando uma criança nas costas com os dizeres: "África Mãe, oásis, ventre fértil que o mundo às vezes reconhece, outra vez se recusa a pensar, que foi lá que a história começou desde que o mundo é mundo" se referiria à ideia de uma nação mundial nascida da África, bem como a preocupação da exposição em retratar a vida dos africanos antes do tráfico negreiro e dos negros na diáspora. 


\section{Figura 3 - Escultura Mãe- África}

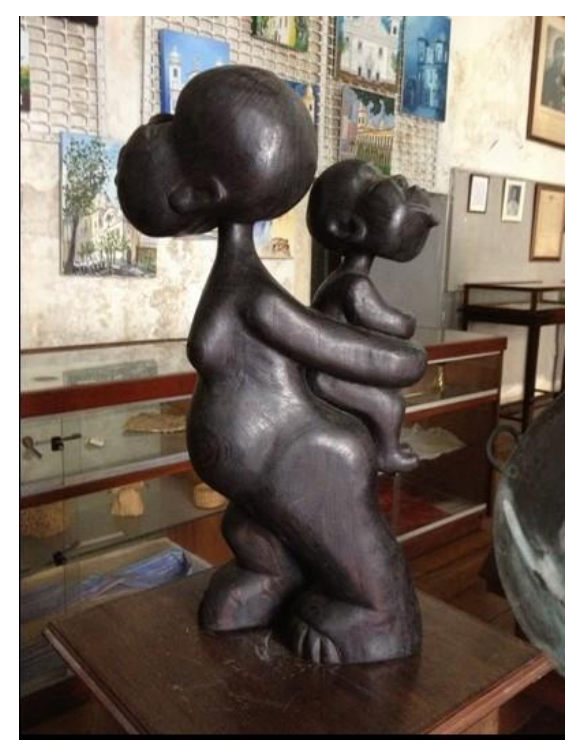

Fonte: Website do Museu do Negro: http://irmandadedoshomenspretos.org.br/site/ Acessado em 28 jul.2016. Autor desconhecido.

O propósito é recontar verdadeiramente a história do negro no Brasil, e além de recontar essa história, não aquelas que aprendemos em sala de aula, contar a história do negro na contemporaneidade. Nós contamos a história do negro em $360^{\circ}$ graus, da chegada do negro, o dia-a-dia, a arte. A nossa proposta é essa, é parar com essa coisa de "ou virou bandido, ou virou vagabundo", essas coisas todas ${ }^{6}$ (PASSOS, 2016, Informação oral).

A exibição do acervo atual é bastante diversificada contando com objetos históricos, como os utensílios de trabalho manuseados pelos africanos, correntes e instrumentos de tortura, cerâmicas produzidas em comunidades quilombolas, atabaques, máscaras e totens africanos e estandartes da campanha abolicionista; pinturas e esculturas que retratam a vinda para o Brasil nos navios negreiros, e figuras consideradas ilustres como a Princesa Isabel e o Conde D'eu, D. João VI, Zumbi dos Palmares, o Marechal João Baptista de Matos, a atriz Ruth de Souza; fotografias de negros

\footnotetext{
${ }^{6}$ Ricardo Passos, historiador e coordenador do Museu do Negro. Responsável pela curadoria da atual exposição. Entrevista cedida no Museu do Negro em 07/07/2016.
} 
escravizados e de negros livres que atuaram no movimento abolicionista como Luís Gama, José do Patrocínio, André Rebouças, Joaquim Nabuco, Cruz e Souza, bem como de figuras políticas do século XX, como os senadores Benedita da Silva e Abdias Nascimento e do deputado José Miguel; documentos escritos como cartas de compras de escravos, jornais abolicionistas e a Revista Ilustrada de 1888 , que tratam do tema da luta contra a escravidão e a abolição, bem como diversos documentos ligados à Irmandade de Nossa Senhora do Rosário e São Benedito dos Homens Pretos.

Mapeando a história da população negra com enfoque na diáspora, na experiência do cativeiro e no movimento de luta abolicionista, a exposição traz referências dos modos de vida dos africanos, anteriores à escravização. No entanto, o que predomina nos objetos selecionados é o período escravista da história brasileira, com ênfase na imagem do negro escravizado e sua luta por liberdade, bem como, o vínculo com uma tradição monarquista centrada na figura da princesa Isabel, que é retratada como a Redentora do Império. Os instrumentos de tortura, os objetos pessoais, fotografias e jornais ligados aos líderes da luta pela liberdade retirados de seu tempo e introduzidos em nossa contemporaneidade se tornam objetos-portadores-de-sentido, que alimentam valores do passado, o sofrimento das vítimas da escravidão, por exemplo, para atender demandas do presente.

O culto à memória da escravização e dos personagens envolvidos com a resistência a esse sistema e a luta pela liberdade fica evidente, no sentido de se render homenagem à memória das vítimas da escravidão, defender a dignidade de seus descendentes e afirmar a incomensurabilidade do seu sofrimento, assim como permitir aos negros, hoje, acionarem a memória do passado escravizado de seus ancestrais, a memória dos ritos, músicas e danças que estes trouxeram da África ou foram por eles aprendidos nas senzalas.

\section{Museu do Negro: o histórico e o sagrado}

Professores que visitam o Museu do Negro relataram que os objetos ligados à escravidão, relativos ao castigo ou ao trabalho, são os que mais chamaram a atenção dos 
alunos, seja por dar materialidade à crueldade da escravidão, seja por evidenciar o cotidiano daqueles que foram privados de sua liberdade, conforme nos contou o professor Renan, que atua em turmas do Ensino Fundamental da rede municipal do Rio de Janeiro, em uma escola localizada na Zona Norte, no bairro de Cascadura, e visitou o Museu do Negro em março de 2016:

Eu achei o museu de um caráter de imagem muito diverso, muito recheado de imagens interessantes, de coisas que são faladas na sala de aula. Então isso é muito interessante para os alunos verem em forma de imagem, não só de texto, aquilo que foi trabalhado em sala de aula. Às vezes o espaço da sala de aula é muito reduzido, em questão disso, mesmo que tenha recursos tipo informática. Apresentar um slide não é a mesma coisa de você ver um objeto diretamente ali, então é uma sensação totalmente diferente do que estar dentro da sala de aula (SILVA, R., 2016. Informação oral).

De acordo com o professor Eduardo ${ }^{8}$, atuante na rede estadual de educação, e atuante no Ensino Fundamental e Médio, os objetos de castigo geraram debates na turma por de alguma forma "provar" o caráter desumano da escravidão, em detrimento de discursos relativizantes, que defenderiam a convivência harmônica entre senhores e escravizados:

Por que eu acredito que na experiência material não só a experiência digamos assim, puramente no campo das ideias. Quando você fala com o aluno sobre as situações do negro, as violências que eles sofriam dos senhores de escravos, a questão do transporte das chamadas peças, na época. É muito diferente entre você falar para o aluno e eles absorverem aquilo depois de ter visto a matéria. A questão da realidade, por exemplo quando você vê as peças que prendiam os escravos no pescoço, nas pernas, nos braços, traz um impacto, porque ele vê que aquilo é real, é realmente uma coisa que fez parte da história, fez parte da vida de

\footnotetext{
${ }^{7}$ Renan Gonçalves da Silva. Professor de história do município do Rio de Janeiro, leciona para turmas do $6^{\circ}$ ao $9^{\circ}$ ano do Ensino Fundamental. Entrevista cedida no Instituto de Filosofia e Ciências Sociais em $07 / 07 / 2016$.

${ }^{8}$ Eduardo Francis Gomes da Silva. Professor de história do Estado do Rio de Janeiro, leciona para turmas de ensino fundamental e médio, em duas escolas da Baixada Fluminense, uma na cidade de Belford Roxo e outra em São João de Meriti. Visitou o Museu do Negro em novembro de 2015. Entrevista cedida em $11 / 07 / 2016$.
} 
pessoas que existiram verdadeiramente, não e uma espécie de conto de fadas ou um tipo de subjetividade relativa que pode não ter sido (SILVA, E., 2016. Informação oral).

Os relatos acima evidenciam que, nas salas de aula da educação básica, a escravidão segue sendo uma "questão sensível”, uma vez que, conforme Alberti (2013, p.35) afirmou, o tema envolve uma injustiça em relação a determinado grupo, nesse caso, a população negra. Professores de diversos segmentos relatam problemas para tratar essa questão. Lorene dos Santos (2013, p. 74) atribui essa dificuldade a uma ultrapassada tradição de se caracterizar historicamente a população negra exclusivamente enquanto mão de obra escravizada, enfatizar os horrores vivenciados no cativeiro, numa abordagem da relação de dominação que ignora o papel e atuação dos escravos como sujeitos de experiência. Por outro lado, ignorar a face violenta e desumanizadora da escravidão poderia fortalecer as ideias de convivência harmoniosa, e reavivar o mito da democracia racial.

O Museu do Negro oferece subsídios para problematizar discursos eurocêntricos e desmitificar a ideia de passividade e vitimização dos negros na medida em que seu acervo ressalta referências aos castigos corporais [figura 4] e exalte a figura da Princesa Isabel como a "Redentora" [figura 5], ao mesmo tempo em que são destacados elementos de resistência como Zumbi, o culto à Escrava Anastácia e aos líderes do movimento abolicionista [figura 6], bem como negros “de sucesso" como Marechal João Baptista de Matos, provedor da irmandade que foi responsável pela criação do museu e o primeiro negro alcançar tal cargo no Exército Brasileiro, e a atriz Ruth de Souza. A multiplicidade de personagens históricos evocados pela exposição permite o reconhecimento dos negros enquanto agentes de sua própria história e a explicitação das diversas formas de resistência, evitando assim, visões limitadas dos negros como sujeitos passivos, restritos à dominação e vitimização, sem deixar de reconhecer, no entanto, a violência e a desumanização com que eram tratados. 
Figura 4- Recorte de jornal comemorando o retorno dos restos mortais da Princesa Isabel ao Brasil em 1953

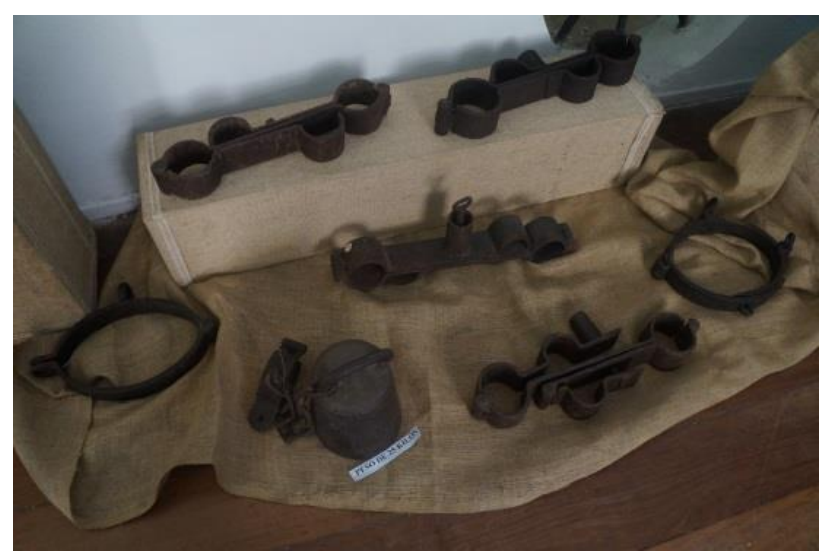

Fonte: Website do Museu do Negro: http://irmandadedoshomenspretos.org.br/site/ Acessado em 28 jul.2016.

Figura 5- Instrumentos de aprisionamento dos escravizados.

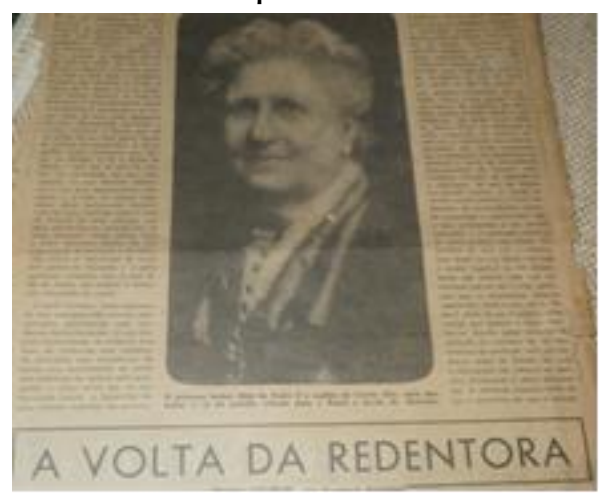

Fonte: Elaborada pelo autor, 2016.

Figura 6- Retratos dos abolicionistas

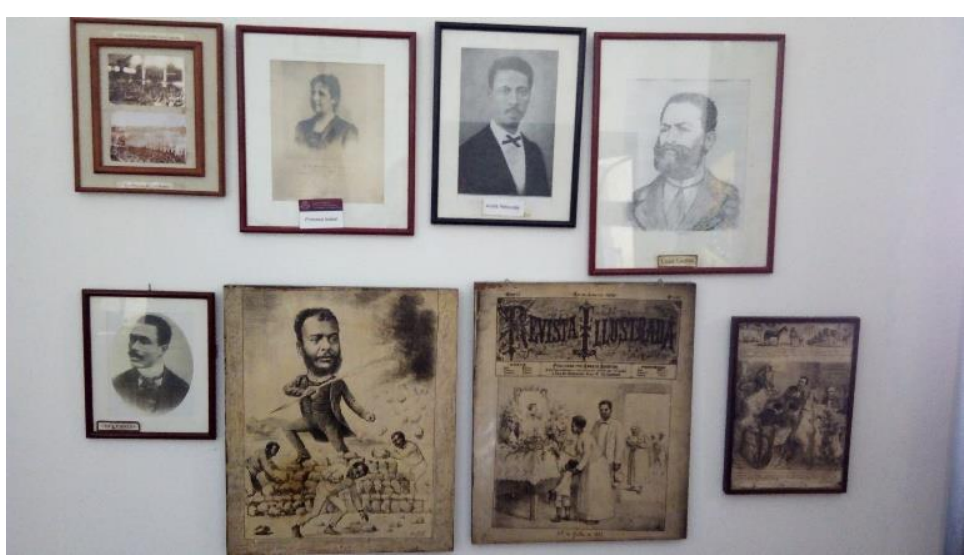

Fonte: Elaborada pelo autor, 2016. 
Tanto nas diversas visitações ao Museu do Negro, quanto nas entrevistas dos professores e alunos que o frequentaram, chamava à atenção a abordagem que o Museu do Negro faz das manifestações culturais afro-brasileiras, uma vez que estão presentes em todo o discurso museológico. A narrativa histórica proposta pela instituição dialoga com o artesanato, com a pintura, a escultura e, especialmente, com a religiosidade afrobrasileira. Consideramos que tais manifestações culturais afro-brasileiras estão intimamente vinculadas a uma posição política como espaços de resistência a dominação, portanto, pertinentes a um ensino de História comprometido com a reavaliação da agência histórica dos negros.

O Museu do Negro, apesar de não utilizar linhas cronológicas, propõe a construção de uma narrativa histórica que remonta a experiência dos africanos anterior ao tráfico, perceptível, por exemplo, em artefatos de ferro que aludem ao domínio da metalurgia, conhecimento técnico trazido da África. Além disso, estão expostos também, máscaras africanas e atabaques que são uma mostra da riqueza cultural e artística dos africanos, juntamente com imagens que retratam navios negreiros e portos de saída de escravizados. Diante disso, destacamos a abordagem integrada entre os processos históricos e as manifestações culturais, isto é, a forma com que o museu mobiliza manifestações culturais, relacionadas ao contexto em que eram praticadas, para a partir delas contar a história afro-brasileira desde a diáspora, atravessando a experiência do cativeiro e o movimento de luta abolicionista.

Se consideramos que, de acordo com Mello (2013, p.46), "a cultura não são cultos e costumes apenas, mas as estruturas de significado por meio das quais os indivíduos dão forma à sua experiência", a representação das práticas culturais, conforme o Museu do Negro a faz, pode ser entendida como uma construção ideológica e mental calcada na maior compreensão das estruturas e dos comportamentos sociais dos indivíduos. Tal perspectiva permitiria, no campo do Ensino de História, o enfoque nas transformações no tempo e no espaço pelas quais passaram as práticas culturais, compreendendo-as em sua dinâmica, mutabilidade e em suas permanências. Os objetos em exposição, desse modo, não seriam concebidos como elementos isolados e nem como vestígios fragmentados, pois estariam articulados a práticas culturais arraigadas e ocupando lugares relacionais, 
que levariam em consideração os elementos históricos constitutivos de sua memória e identidade.

No que tange ao período de vigência do regime escravista, assim como se pode observar a violência cotidiana à qual os indivíduos escravizados estavam submetidos, a partir dos objetos de tortura expostos, concomitantemente, a exposição destaca as formas de resistência através dos objetos da cultura quilombola e a devoção aos santos negros católicos, em torno dos quais se organizaram as irmandades, e de figuras de resistência emblemáticas a escrava Anastácia, Zumbi dos Palmares e Pai Joaquim de Angola. Assim, na representação desse período histórico, nos chamou a atenção a interação entre a resistência e a sobrevivência da população negra com o âmbito religioso.

Em todas as salas da exposição existem diversas imagens de Nossa Senhora do Rosário e de São Benedito seja em formas de esculturas em diversos tamanhos e dimensões ou em papel que percorrem os três espaços do museu [figura 7]. Da mesma forma são cultuados a Escrava Anastácia, Zumbi dos Palmares, Pai Joaquim de Angola e os antepassados africanos de uma forma geral. Diante disso, duas questões nos parecem bastante significativas: a percepção dos ritos religiosos como forma de resistência e a convivência espacial entre práticas religiosas de diferentes matrizes.

Figura 7- Mesa do livro de visitantes do Museu do Negro

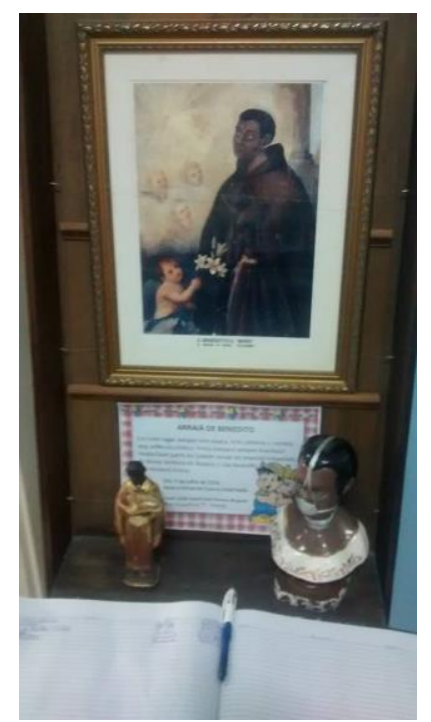

Fonte: Elaborada pelo autor, 2016. 


\section{Entre a cruz e o terreiro}

A exibição de coleções direcionadas para a religiosidade é uma marca do Museu do Negro, tanto que o site da instituição já o anuncia como um museu-devoção, devido à quantidade de objetos que são alvos de culto. Para além da devoção aos padroeiros da irmandade, Nossa Senhora do Rosário e São Benedito, também são considerados sagrados a Escrava Anastácia, Zumbi, Pai Joaquim da Angola, e até mesmo a Princesa Isabel. Zumbi, símbolo da resistência quilombola, é homenageado com o título de rei e é representado através de uma pintura, seguida de uma oração, através da qual os fiéis rogam pela sociedade, emprego e por seus lares. De acordo com o trabalho de campo de Paiva (2007a, p. 215), é possível se observar os pedidos dos fiéis e os agradecimentos que são depositados em moedas e notas de um real diante da imagem.

A devoção no museu também fica evidente na figura da escrava Anastácia, que simbolizaria as inúmeras vítimas da violência e do horror dos castigos físicos. Negra de olhos azuis e com uma máscara de ferro na boca, as representações de Anastácia são numericamente maiores do que as dos santos padroeiros da irmandade. Paiva (2007b, p. 5) relata que o culto a Anastácia teve início no museu quando, na década de 1970, Yolando Guerra expôs um quadro da escrava que ficava no museu na missa de 13 de maio. Embora não seja considerada santa pela Igreja Católica, a escrava Anastácia é cultuada na Umbanda, e muitos de seus devotos se dirigem às esculturas e pinturas da escrava trazendo pedidos e oferendas, fazendo do museu um espaço de culto, onde realizam suas rezas [figura 8].

Figura 8- Altar para Anastácia

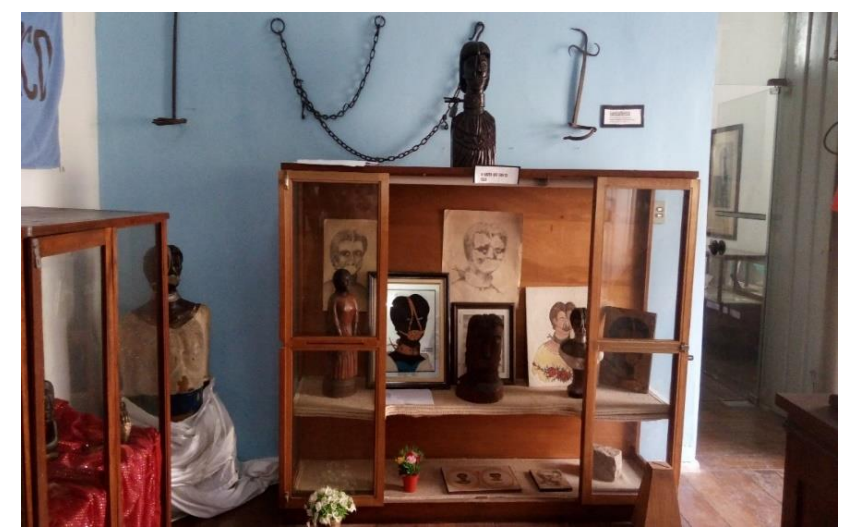

Fonte: Elaborada pelo autor, 2016. 
O culto a Anastácia, representada em diversas pinturas e esculturas em todos os tamanhos e formas é tão intenso que muitos fiéis conhecem o museu como dela, como por exemplo, a senhora Maria Januário ${ }^{9}$, que nos interpelou enquanto fazíamos fotografias da exposição, pedindo informações sobre onde deveria deixar sua oferenda para Anastácia.

Eu conheci o museu da Anastácia quando ele era na Uruguaiana, da Uruguaiana veio para cá. Mas esse museu é muito antigo já e todo mundo o procura justamente por causa da Anastácia, porque a Anastácia, eu não sei se você sabe, ela também faz milagre. A Anastácia faz milagre. Os escravos também sofreram muito, então, tem São Benedito, Santa Sara. Quer dizer, por isso, eu venho aqui nesse museu. Porque muita coisa que a Anastácia passou, eu também passei, entendeu? Então eu olho pra ela e relembro, vejo que a minha cor, aqui minha filha, é nada vezes nada. Vem gente de tudo quanto é país para conhecer, justamente da minha cor, porque eu sou negra com honra, mas vem muita gente aqui. Eu sou tudo, eu trabalho de faxineira, eu sempre venho aqui. Todas as quintas-feiras eu venho aqui, entendeu? Mas não se preocupa não, que vem muita gente. Eu acho também que o país, do jeito que o país está, nós, negros, tínhamos que vir aqui para falar com ela, para dar um jeito no racismo e outras coisas mais que a gente passa (JANUÁRIO, 2016. Informação oral).

A diretoria do museu também aponta Anastácia como figura mais procurada pelos visitantes, inclusive a nível internacional:

A maioria dos estrangeiros, americanos, franceses, holandeses, eles vem atrás da Anastácia, porque o nosso cargo chefe é a Anastácia. Nós não podemos falar de Anastácia abertamente porque ela não é reconhecida pela igreja, porque não tem nada que comprove a existência dela. Ela é reconhecida pela umbanda. A Anastácia, ela foi levada para umbanda por isso. Ela está lá representando a jovem negra feiticeira que não se deixou levar, que não abaixa a cabeça, está lá na umbanda. [...] A TV francesa esteve aqui, para falar sobre negro, sobre Anastácia. Foi no dia 10 de dezembro, porque em janeiro ia ser lançada em Portugal, França, Alemanha e Holanda, a novela "Lado a lado", e nessa novela, eles falariam de João Candido e da irmandade. Era pra ser uma entrevista de

\footnotetext{
${ }^{9}$ Maria Januário é empregada doméstica e foi uma das visitantes do Museu do Negro entrevistadas durante o processo de pesquisa de campo. Entrevista cedida ao autor em 11/07/2016.
} 
meia hora e nós ficamos aqui a tarde inteira. Depois veio a TV holandesa atrás de Anastácia querendo saber dela (PASSOS, 2016. Informação oral).

A Anastácia, em conjunto com outras imagens de escravizados e objetos com que eram torturados, comporia uma "memória do sofrimento". A questão do sacrifício e da vida de luta constituiriam aspectos fundamentais no processo de sua atribuição como seres sagrados, e o culto a sua alma passou a ser visto como entidade "capaz de proteger os indivíduos contra o mal e o infortúnio, assumindo, assim, uma dimensão mágicoreligiosa" (PAIVA, 2014, p. 57). Não é raro que os cultos a Anastácia aconteçam ao som da missa, que está sendo realizada na nave da igreja, no primeiro andar. No entanto, segundo um dos historiadores do museu, os cultos convivem sem problemas.

Eles não tem nenhum problema contra isso, os irmão comuns como eu, eles não falam nada, nunca falaram. O problema é só corregedoria, não é nem por eles, e sim porque eles são cobrados. Por exemplo, esse negócio de ultrapassar os limites, eles vão ser chamados a atenção, mais ou menos isso, mas os irmãos em geral e até os que vem prestar homenagem a Anastácia, não tem nenhum conflito $^{10}$ (FERNANDES, 2016. Informação oral)

A convivência harmoniosa tem seus limites. O culto a Anastácia é permitido e não causa problemas com os membros da Irmandade, todavia, a irmandade é católica, e as tensões existem, especialmente, quando figura de Anastácia se sobressai à figurada de Nossa Senhora do Rosário: "Não pode falar dia da Anastácia, tem que ser dia da Nossa senhora do Rosário. Não pode dizer que a igreja é da Anastácia" (PASSOS, 2016, Informação oral).

Outra representação que atrai devotos é a do Pai Joaquim de Angola, que muitos identificam como Preto Velho, entidade cultuada nas religiões de matriz africana [figura 9]. Pai Joaquim aparece em uma fotografia e duas grandes esculturas, todavia nenhuma das representações recebe seu nome. Uma das esculturas retrata um homem negro de cabelos grisalhos fumando um cachimbo, sem inscrições de título e autor da obra. A

\footnotetext{
${ }^{10}$ Bruno Fernandes, historiador e vice coordenador do Museu do Negro. Entrevista cedida em 07/07/2016.
} 
segunda escultura se chama "Cabeça de Negro", e foi doada ao Museu do Negro pelo artista plástico argentino Humberto Cozzo [figura 10].

Figura 9- Escultura de Pai Joaquim

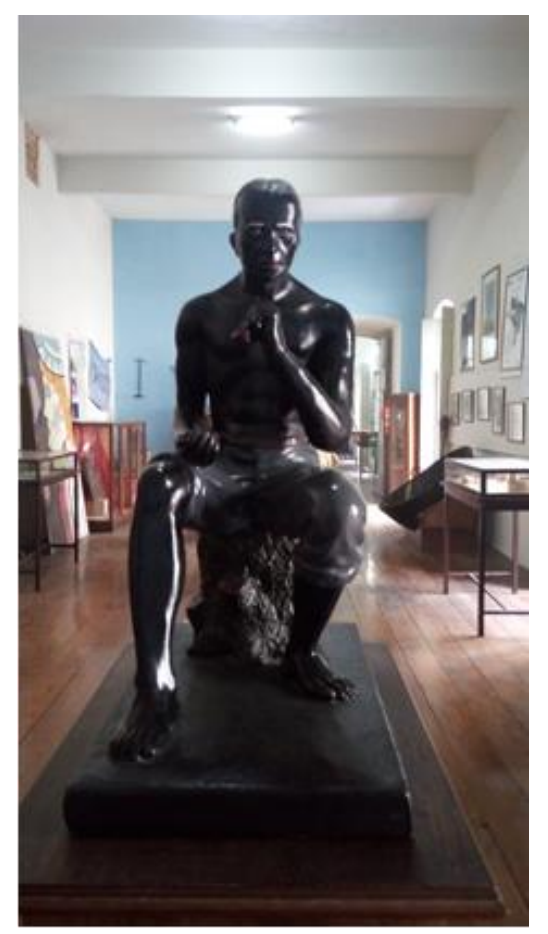

Fonte: Website do Museu do Negro: http://irmandadedoshomenspretos.org.br/site/ Acessado em 28 jul.2016. Autor desconhecido.

Figura 10- Escultura Cabeça de Negro

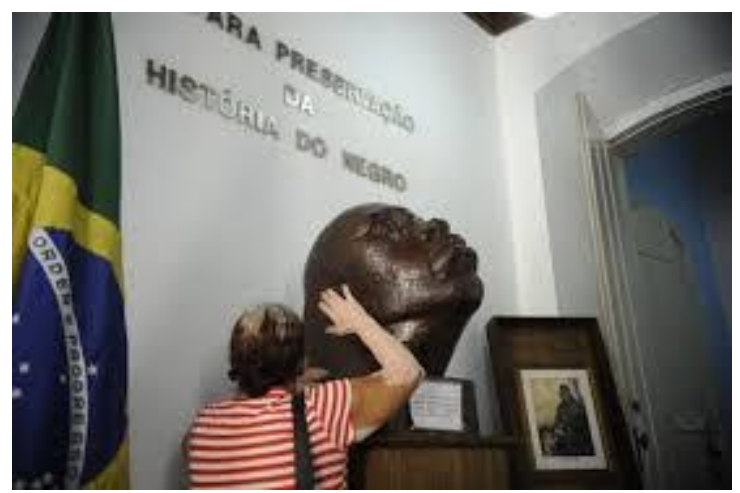

Fonte: Website do Museu do Negro: http://irmandadedoshomenspretos.org.br/site/ Acessado em 28 jul.2016. Humberto Cozzo, 1970. 
É comum observar nas visitas ao museu, algum devoto falando no ouvido dessa escultura, outros deixam cigarros, moedas e flores aos pés de ambas. O museu, portanto, reúne em sua exposição diferentes expressões da religiosidade afro-brasileira, atribuindo historicidade as mesmas. Ricardo Passos e Bruno Fernandes, responsáveis pela exposição, concordam que o objetivo era uma abordagem ampla, para que o maior número de negros pudesse se identificar:

\begin{abstract}
A gente busca trazer o negro na religião europeia, europeia não, na verdade, ela é asiática, a religião cristã, e influência do negro aqui no Brasil, com essa vertente cristã. Mas também, o negro que não apagou suas origens, que no mesmo tempo que ele assistia a missa, ele ia para o terreiro. Na verdade o que a gente busca é mostrar a história de todos os negros convivendo nesse espaço, porque o negro não é uma coisa só. São várias coisas, vieram de vários países da África, onde tinham etnias diferentes, idiomas diferentes. Eles eram pessoas diferentes. Porque se colocar assim: "o negro é da África", mas eles não vieram de um lugar só, vieram de lugares diferentes, com culturas diferentes. Tudo isso que se refere ao negro, os antepassados que deram origem aos negros de hoje, de eles estarem aqui no Brasil, é importante para o museu, não tem como falar de um negro, de uma etnia, são várias, porque tudo que tem negro no Brasil interessa a nós (FERNANDES, 2016. Informação oral).
\end{abstract}

O espaço físico entre o museu e a igreja, como já mencionamos anteriormente, não é o único laço que os une. O museu pertence a uma irmandade católica, portanto, é ela que fornece todo o suporte financeiro do museu. Trata-se, portanto, de uma relação de poder. A representação do negro feita pelo Museu do Negro estaria à mercê da seleção orientada pelos princípios da irmandade, logo, por princípios católicos, conforme Ricardo Passos, historiador e diretor do museu: “A nossa irmandade, que é a primeira, pisa em ovos, com uma certa ressalva com a tradição africana, que poderá levar para o lado do culto religioso mais africano, ou seja, o candomblé". Todavia, se por um lado, a Irmandade de Nossa Senhora do Rosário e São Benedito dos Homens Pretos no Rio de Janeiro ainda constranja a representação aberta dos cultos de matriz afro-brasileira, por outro, no cotidiano do museu, as referências a estes estão postas, e são identificadas e acessadas por seus fiéis, conforme relata Bruno Fernandes: 
Embora ultimamente a irmandade não goste muito da tradição, prefira que seja uma coisa mais católica, não tem como não ser. Você viu ali na frente, tem uma imagem do Pai Joaquim, as pessoas vem colocar oferendas para ele, colocam cigarros, moedas, colocavam guias. Só pedimos para não colocarem guias, não que a gente tenha algo contra, mas é porque um senhor veio aqui e falou, que isso ia causar problema para o museu. Na verdade é difícil, porque o museu tem que ser um espaço livre. É complicado, na maioria das vezes eles levam na boa, é só a gente pedir direito. Tem um senhor que vem todas as segunda feiras, às 14 horas da tarde. Ele roda o museu todo, falando com todos, com seus ancestrais, com Zumbi, Pai Joaquim, Anastácia, e no final ele faz um gesto, dá tchau e vai embora. Cada um tem uma maneira de demonstrar e não tem nenhum problema contra isso. Eu acho ótimo, porque a ideia é essa mesmo, esse é o espaço para as pessoas virem e se sentirem acolhidas. Isso aqui é uma casa de cultura, mas também tem uma espiritualidade que é do negro (FERNANDES, 2016. Informação oral).

Grande parte das manifestações culturais afro-brasileiras são constituídas sob a égide do catolicismo popular, de forma híbrida. Em seu intento de resgatar e preservar a história dos negros, o Museu do Negro não deixa de mobilizar a cultura afro-brasileira, e não exclui as manifestações religiosas de seu repertório. O estudo da cultura afrobrasileira realizado a partir de uma abordagem histórica, em que estão contrastadas, confrontadas e em diálogo outras formas de abordagem históricas e culturais, nos parece um caminho favorável para edificar a diversidade cultural e a diferença, colaborando para a criação e para o reconhecimento de espaços plurais, de negociações e livres de estereótipos. Assim como Pereira e Roza (2012, p. 103), acreditamos que o "estudo dessas imbricações, e das negociações feitas, na história, pode ser um primeiro passo para que estudantes e professores venham a compreender a trajetória histórica das práticas culturais, suplantando preconceitos comumente manifestos em relação a elas".

Nesse sentido, o acervo do Museu do Negro, da forma como está exposto, oferece subsídios para a realização de um trabalho pedagógico que problematize os discursos pejorativos sobre os cultos de matriz afro-brasileiras, e ainda lança luz sobre a possibilidade de convivência não agressiva, nem física nem simbolicamente, entre diferentes matrizes religiosas. Mais do que a ideia de tolerância religiosa, isto é, de que as diferentes matrizes religiosas podem conviver sem se agredir, a exposição acena para a perspectiva da negociação entre as diferentes culturas. No museu, as tentativas de expor 
objetos que preservem a memória da Irmandade, ao mesmo tempo em que tenta narrar a história de vida e de lutas da população negra, reuniu em um espaço culturas diferentes, porém de "margens deslizantes", que, juntas, produziriam, segundo Bhabha (1998, p.51), um espaço em que se ultrapassaria "as bases de oposição dadas e abre um espaço de tradução: um lugar de hibridismo, para se falar de forma figurada, onde a construção de um objeto político que é novo, nem um e nem outro", ou seja, um espaço de negociação.

Negociação é um conceito fundamental para compreensão de uma cultura negra que não pode e não deve ser explicada através de oposições binárias, como negro $x$ branco, catolicismo x umbandismo, sagrado x profano. O Museu do Negro, em sua exposição, explicita que construir uma narrativa sobre história afro-brasileira não significa buscar uma essência africana, mas sim reconhecer que não existem formas puras nesse processo. "Somos sempre diferentes e estamos sempre negociando diferentes tipos de diferenças" (HALL, 2003, p. 346), como no culto à Anastácia, que acontece ao som da missa e odor de incenso, e, também, na narrativa construída pelo professor que passeia pelo museu com seus alunos relacionando conceitos historiográficos, conhecimento pedagógico e a experiência de cada estudante com quem dialoga.

Considerando que estudo da cultura e da história afro-brasileiras está orientado pelo interesse na revisão do passado dos negros nas narrativas históricas, pela investigação da cultura, valorização e positivação da diversidade e da diferença, acreditamos que uma visita ao Museu do Negro associada a um trabalho pedagógico que aproxime o aluno da noção de que a cultura é historicamente construída e de que as diferentes culturas estão sempre em negociação é uma opção bastante profícua. No espaço do museu, os objetos ligados à religiosidade despertam o interesse e a curiosidade e são apontados por muitos estudantes como o aspecto mais marcante da visita. Segundo o professor Renan, da rede pública municipal da região de Madureira, esse foi o aspecto mais comentado pelos alunos, que tiveram pouca resistência à temática da religiosidade de matriz afro-brasileira:

Os alunos, em geral, conseguiram absorver bem a questão (religiosa), um ou outro ainda argumenta achando que é aula sobre macumba, sobre 
religiões africanas, mas em geral eles aceitam bem muitos são ... O público é muito diverso então isso também me ajuda bastante a falar sobre diversas culturas, sobre diversos tipos de assuntos religiosos (SILVA, R., 2016, Informação oral).

De acordo com Renan, parte dessa aceitação se deve ao fato de os alunos já terem familiaridade com a cultura afro-brasileira, que seria muito presente no bairro em que vivem.

Aquela região ali, de Cascadura, de Cavalcante até Madureira, é um bom reduto de cultura negra, então isso facilita bastante o trabalho. Não só morando em Madureira, mas muitos que também são da região da grande Madureira, vamos dizer assim. Então eles têm muitos contatos, por exemplo, com o jongo da Serrinha ou a Baiana, aquela que fica de frente para o Mercadão de Madureira. O próprio Mercadão. Eles terem contatos com essas coisas que facilita bastante o trabalho (SILVA, R., 2016, Informação oral).

O estranhamento e o desconhecimento sobre a cultura afro-brasileira, bem como sua relação com a história de lutas e resistências dos negros no Brasil favorece a adesão a discursos "demonizadores" de suas práticas. Muitas dessas visões negativas podem estar tão arraigadas ao imaginário dos estudantes que somente a fala do professor em sala de aula pode não ser suficiente para provocar a criticidade do aluno. Acreditamos que o Museu do Negro proporciona uma exposição interessante para um primeiro contato com tais manifestações culturais.

Estudantes da rede estadual do Rio de Janeiro, do Colégio Estadual Santa Amélia, situado na cidade de Belford Roxo, visitaram o Museu do Negro em 29 de maio de 2016. Entrevistamos 30, dos 45 estudantes que participaram da atividade. Todos os entrevistados apontaram que a visita ao museu, acompanhada do trabalho de seus professores, possibilitou a desconstrução de muitos preconceitos sobre a cultura afrobrasileira. Apesar de $78 \%$ dos estudantes entrevistados relatarem que ouviriam constantemente falar sobre história e cultura afro-brasileira em suas escolas, e somente 3\% afirmarem que só o fazem raramente, a temática da religiosidade afro-brasileira 
representada pelo museu parece ter sido uma novidade na medida em que $97 \%$ dos entrevistados assinalaram que tiveram suas concepções transformadas após a visita ao Museu do Negro:

A cultura afro-brasileira é pouquíssimo comentada hoje nas escolas, se pararmos para fazer uma pesquisa numa escola sobre isso, poucos irão saber responder. Muitos falam só sobre "macumba", capoeira, mas a cultura não é apenas isso. Os professores deveriam falar sobre essa cultura para que as crianças e adolescentes entendam sobre a cultura, que não é simplesmente uma cultura e sim uma identidade de quem gosta e adquiri' (PEREIRA, 2016).

Outros apontaram que o conhecimento sobre a religiosidade afro-brasileira a partir de um contexto histórico ajudaria, inclusive, no combate ao preconceito e na percepção de que tais cultos fazem parte de sua própria história, concebendo-as como parte de uma herança cultural:

O conhecimento e a amplitude da história africana nas escolas, ajudam ao entendimento e a desconstrução do preconceito enraizado na cultura, e por consequência, em nossas mentes. Essa abrangência, no entanto deveria ser melhorada ao conhecimento prático para todos os alunos e não só apenas um grupo (MARQUES, 2016). ${ }^{12}$

Com a falta de conhecimento dessas culturas, muitas pessoas julgam sem ter total convicção sobre o assunto. Com a influência de sua família, tornam-se racistas desde crianças por tal influência. Com parte do ensino voltado para essas culturas, diminuirá esse preconceito tão grande e tão presente na sociedade que vem matando a cada dia (ABREU, 2016) ${ }^{13}$.

Os estudantes foram entrevistados após a visitação da referida exposição. Quando perguntados sobre a presença de práticas racistas em sua unidade escolar, somente 6\% responderam negativamente. Os outros $94 \%$ reconheceram a existência de racismo na

\footnotetext{
${ }^{11}$ Fernando Pereira, estudante do $3^{\circ}$ ano do ensino médio, no Colégio Estadual Santa Amélia, em Belford Roxo. Entrevista concedida no Museu do Negro em 29/05/2016.

12 Jéssica Marques, estudante do $3^{\circ}$ ano do ensino médio, no Colégio Estadual Santa Amélia, em Belford Roxo. Entrevista concedida no Museu do Negro em 29/05/2016.

${ }^{13}$ Danielly Abreu, estudante do $3^{\circ}$ ano do ensino médio, no Colégio Estadual Santa Amélia, em Belford Roxo. Entrevista concedida no Museu do Negro em 29/05/2016.
} 
escola e atribuíram as injúrias raciais que já presenciaram aos seguintes fatores: cor da pele (66\%), tipo de cabelo (66\%), religião (53\%) . Quando questionados sobre que pontos de vista teriam sido alterados a partir da visita, $62 \%$ dos estudantes falaram sobre a religiosidade ou tolerância religiosa e 56\% de alteridade cultural. A maior parte dos alunos apontou que o conhecimento sobre a cultura afro-brasileira contribuiu muito na construção de seu saber histórico e 37\% deles não acredita que tal conhecimento seja eficaz no combate ao racismo, conforme o relato abaixo:

O meu comentário é referente a uma das perguntas. Infelizmente por mais que tenha um grande conhecimento e ensinamento sobre a cultura afro-brasileira, ainda não é eficaz para combater o racismo, é triste porque o preconceito e o racismo vêm de dentro de casa, É triste porque é incrível conhecer e saber cada vez mais de nossas raízes. Ser negro é um orgulho e ter reconhecimento é mais gratificante ainda (MARIA, 2016). ${ }^{14}$

Acho que a questão do racismo e intolerância racial tem uma base histórica e cultural muito forte, que se esconde pelo discurso de um país sem preconceito, e que mantém atos de intolerância comuns em questões de piadas, apelidos e conceitos de beleza impostos pela sociedade que dizem ser os corretos sem levar em consideração a miscigenação e a diversidade de um país como o Brasil. o conhecimento sobre a cultura afro-brasileira só é, de fato, eficaz se combinado com uma série de novos pontos de vista sociais e a diminuição de preconceitos sociais historicamente impostos (PERPÉTUO). ${ }^{15}$

O posicionamento dos estudantes sobre a necessidade de criar novos mecanismos para combater o racismo, sua disposição a problematizar a marginalização da história e, principalmente, da cultura afro-brasileira, bem como, entender a religiosidade afrobrasileira como uma herança cultural, que deve ser respeitada e valorizada nos demonstra que a ação educativa organizada pelos professores a partir da observação e do debate sobre a exposição do Museu do Negro teve resultados positivos.

\footnotetext{
${ }^{14}$ Lívia Maria, estudante do $3^{\circ}$ ano do ensino médio, no Colégio Estadual Santa Amélia, em Belford Roxo. Entrevista concedida no Museu do Negro em 29/05/2016.

${ }^{15}$ Augusto Perpétuo, estudante do $3^{\circ}$ ano do ensino médio, no Colégio Estadual Santa Amélia, em Belford Roxo. Entrevista concedida no Museu do Negro em 29/05/2016.
} 
Para além das visitas que recebe gratuitamente, o Museu do Negro desenvolve outro projeto educativo, o "Museu nas escolas", em que os objetos do museu que podem ser transportados são levados às escolas da Zona Oeste e da Baixada Fluminense, ou seja, áreas mais afastadas da região central do Rio de Janeiro, que não têm condições de locomoção.

\begin{abstract}
A gente recebe as escolas aqui, que agendam com a gente, mas quando a escola tem pouca verba e não tem condições de fretar um ônibus para trazer os alunos, o que a gente faz? Se tem um lugar que possamos ir, a gente pega uma amostra de cada parte do museu e levamos até eles, fazendo palestras e chamando muitas pessoas, até de outras escolas também, e levamos o museu até eles (PASSOS, 2016. Informação oral).
\end{abstract}

Sabemos que a exposição não é perfeita. As representações da religiosidade de matriz afro-brasileira que acabam por acontecer em certa clandestinidade, e a ênfase na figura da princesa Isabel quase santificada como libertadora dos negros, o recorte temporal, não oficial, focalizado no período imperial, são aspectos que podem ser problematizados. Tais problemas não inviabilizam o trabalho com o acervo e não desmerecem seu potencial educativo. Acreditamos que precisamos ocupar esses espaços que tem resultado das políticas culturais da diferença, pois, ainda que tenham certas deformidades, elas trazem à tona "elementos de um discurso que é diferente - outras formas de vida, outras tradições de representação" (HALL, 2003, p.342).

\title{
Referências
}

ABREU, Danielly. [Entrevista cedida a] Jessika Rezende Souza da Silva, Rio de Janeiro (RJ), 29 mai. 2016.

AUTRY, Robin. Desegregating the past: the public life of memory in the United States and South Africa. Columbia University Press, 2017.

AZEVEDO, Cecília; ALMEIDA, Maria Regina Celestino. Identidades plurais. In: ABREU, Martha \& SOIHET, Rachel (orgs). Ensino de História: conceitos, temáticas e metodologias. Rio de Janeiro: Casa da Palavra, 2003. 
BHABHA, Homi. O local da cultura. Belo Horizonte: Editora da UFMG, 1998.

BRASIL. Ministério da Cultura, Instituto do Patrimônio Histórico e Artístico Nacional, Departamento de Museus e Centros Culturais. Cadastro Nacional de Museus. Rio de Janeiro, 2006.

FERNANDES, Bruno Alves. [Entrevista cedida a] Jessika Rezende Souza da Silva, Rio de Janeiro (RJ), 7 jul. 2016.

HALL, Stuart. “Que 'negro’ é esse na cultura negra?”. In: HALL, S. Da diáspora: identidade e mediações culturais. Belo Horizonte: Ed. UFMG, 2003.

JANUÁRIO, Maria. [Entrevista cedida a] Jessika Rezende Souza da Silva, Rio de Janeiro (RJ), 11 jul. 2016.

LIMA, Mônica. História da África: temas e questões para a sala de aula. Cadernos

PENESB, Rio de Janeiro, 2006.

LIMA, Mônica. Prefácio. In: PEREIRA, Amílcar Araujo; MONTEIRO, Ana Maria (orgs).

Ensino de história e culturas afro-brasileiras e indígenas. Rio de Janeiro, Pallas, 2013.

LIMA, Mônica. Pela desobediência. Conversa de Historiadoras. Rio de Janeiro, maio de 2016. Disponível em: https://conversadehistoriadoras.com/2016/05/03/peladesobediencia/. Acesso em: 10 dez. 2019.

MARIA, Lívia. [Entrevista cedida a] Jessika Rezende Souza da Silva, Rio de Janeiro (RJ), 29 mai. 2016.

MARQUES, Jessica. [Entrevista cedida a] Jessika Rezende Souza da Silva, Rio de Janeiro (RJ), 29 mai. 2016.

MELLO, Janaina Cardoso de. A representação social da escravidão nos museus brasileiros: interfaces entre a museologia e a história. Sankofa, São Paulo. v. 6, n. 10, p. 43-59, 2013. Disponível em: http://www.revistas.usp.br/sankofa/article/view/88893/0 . Acesso em: 18 dez. 2019.

MOREIRA, Jocimar Telles. [Entrevista cedida a] Jessika Rezende Souza da Silva, Rio de Janeiro (RJ), 7 jul. 2016.

MUSEU DO NEGRO. Acervo. In: MUSEUS DO RIO. Rio de Janeiro, 07 jun. 2016. Disponível em:

https://www.museusdorio.com.br/joomla/index.php?option=com_k2\&view=item\&id=40: museu-do-negro. Acesso em: 20 fev. 2020. 
NORA, Pierre. Entre memória e história: a problemática dos lugares. Projeto História (Revista do Programa de Estudos Pós-graduados em História/Departamento de História, PUC-SP), São Paulo, v.10, p.7-28, 1993.

PAIVA, Andréa Lúcia da Silva. Quando os “objetos" se tornam "santos”: devoção e patrimônio em uma igreja no centro do Rio de Janeiro. Textos escolhidos de cultura e arte populares. v.11, n.1, Rio de Janeiro, mai. 2014. p. 53-70

PAIVA, Andréa Lúcia da Silva. Museu dos Escravos, Museu da Abolição: o Museu do Negro e a arte de colecionar para patrimoniar. In: ABREU, Regina; CHAGAS, Mário de Souza; SANTOS, Myrian Sepúlveda dos. Museus, coleções e patrimônios: narrativas polifônicas. Rio de Janeiro: Garamond, MinC/IPHAN/DEMU, 2007a. p. 203-228.

PAIVA, Andréa Lúcia da Silva. Espaços de devoções: o Museu do Negro narrando histórias. Simpósio Nacional de História, 24. Anais. ANPUH, São Leopoldo, 2007b. Disponível em http://anais.anpuh.org/wp-content/uploads/mp/pdf/ANPUH.S24.0206.pdf . Acesso em 18 dez. 2019.

PASSOS, Ricardo. [Entrevista cedida a] Jessika Rezende Souza da Silva, Rio de Janeiro (RJ), 7 jul. 2016.

PEREIRA, Fernando. [Entrevista cedida a] Jessika Rezende Souza da Silva, Rio de Janeiro (RJ), 29 mai. 2016.

PEREIRA, J.S.P; ROZA, L.M. \&. O ensino de história entre o dever de memória e o direito à história. Revista História Hoje, São Paulo, v.1, n.1, 2012.

PERPETUO, Augusto. [Entrevista cedida a] Jessika Rezende Souza da Silva, Rio de Janeiro (RJ), 29 mai. 2016.

RUBINO, Silvana. O mapa do Brasil passado. Revista do Patrimônio Histórico e Artístico Nacional, Rio de Janeiro, Iphan, n. 24, 1996.

SANTOMÉ, Jurjo Torres. La justicia curricular: el caballo de Troya de la cultura escolar. Madrid: Ediciones Morata, 2011.

SANTOS, Boaventura de Sousa; MENESES, Maria Paula. (Org.). Epistemologias do Sul. São Paulo: Cortez, 2010.

SANTOS, Lorene. Ensino de história e cultura africana e afro-brasileira: dilemas e desafios da recepção a Lei 10.639/03. In: PEREIRA, Amílcar Araujo; MONTEIRO, Ana Maria. Ensino de história e cultura afro-brasileiras e indígenas. Rio de Janeiro: Pallas, 2013. 
SANTOS, Myrian Sepúlveda dos. Entre o Tronco e os Atabaques: a representação do negro nos museus brasileiros. http://www.ceao.ufba.br/unesco. 2000.

SANTOS, Myrian Sepúlveda dos. A escrita do passado em museus históricos. Rio de Janeiro: Garamond : MinC: IPHAN: DEMU, 2006.

SANTOS, Myrian Sepúlveda dos. Canibalismo da memória: o negro nos museus brasileiros. Museus: antropofagia da memória e do patrimônio. Revista do Patrimônio Histórico e Artístico Nacional, Rio de Janeiro: Iphan, n. 31, 2005.

SILVA, Eduardo Francis. [Entrevista cedida a] Jessika Rezende Souza da Silva, Rio de Janeiro (RJ), 11 jul. 2016.

SILVA, Renan Gonçalves. [Entrevista cedida a] Jessika Rezende Souza da Silva, Rio de Janeiro (RJ), 7 jul. 2016.

SOUZA, Marina de Mello. Algumas impressões e sugestões sobre o ensino de história da África. Revista História Hoje, São Paulo, v.1, n.1, 2012. 